\title{
Kroonikaklipp kui kultuuriloo dokument: Hindåsi juhtum
}

\begin{abstract}
Triinu Ojamaa
Teesid: Teise maailmasõja pagulastest kujunes Rootsis välja elujõuline eesti eksiilühiskond. Esimestel aastakümnetel jäädvustas Harald Perten kitsasfilmile rootsieestlaste kultuurisündmusi, tema pärand on hoiul Stockholmis Rootsi Eestlaste Arhiivis. Osa materjali on monteeritud kroonikafilmideks, nii nagu amatööri kasutuses olev tehnika möödunud sajandi keskel võimaldas: lisatud on tiitrid sündmuse ja filmija kohta, mõnikord ka pikemad vahetekstid (suur osa filmidest on helindamata). Teine osa materjalist on ilma algustiitriteta ning hetkel varustatud kohati puudulike arhiiviandmetega. Rootsieestlaste kultuurielu ekspertide ja Eesti Kirjandusmuuseumi ühise ettevõtmisena toimus 2015. aasta juunis Stockholmis Perteni filmide läbivaatamine, et tuvastada filmitud sündmusi ja isikuid. Mõne filmiklipiga kulges töö ladusalt, mõne puhul osutus keeruliseks ja ajamahukaks. Käesolev artikkel kirjeldab ühe filmiklipi analüüsimise käiku ja tuvastamisel üleskerkinud probleeme koos võimalike lahendusteedega. Artikli veebiversioonile on lisatud uurimuse raames subtiitritega varustatud filmiklipp; selle sisuks on eesti pagulaskooride vabaõhukontsert, millega oletatavalt 1940. aastate lõpul tähistati võidupüha (23. juuni).
\end{abstract}

Märksõnad: kroonikaklipp, laulupidu, pagulaselu, rootsieestlased, suvepäevad

\section{Sissejuhatuseks}

2015. aastal andis Rootsi Eestlaste Arhiiv Stockholmis Eesti Kultuuriloolisele Arhiivile üle $16 \mathrm{~mm}$ tummfilmide digikoopiad, millele on jäädvustatud pagulaslaagrite argipäevi, laulupidusid, Eesti Vabariigi aktusi, kirjandussündmusi ning eesti koolide tegevust Rootsis. Materjal on kahesugune: monteeritud kroonikad, mis varustatud tiitritega ning filmiklipid, mida võib käsitleda nn musta materjalina. Viimased ei sisalda ühtki märget selle kohta, mida või keda on filmile üles võetud, samuti mitte seda, kus ja millal on film tehtud. Juunis 2015 kogunesid Stockholmi Eesti Majja eri põlvkondade rootsieestlased, kes on olnud lähedases kokkupuutes eksiilühiskonna kultuurieluga. Mõned neist on ise osalenud eesti elu tähtsündmustel, mõned on kultuuri- ja poliitikategelaste järeltulijad, 
kes mäletavad eksiilühiskonna juhtfiguure oma lapsepõlveaegadest, mõned kuuluvad arhiivi töörühma, mis korraldab rootsieestlaste kultuuripärandit. Kaheksast inimesest koosnev ekspertrühm võttis oma ülesandeks filmitud isikute tuvastamise ning sündmustega seotud info täpsustamise. Arutelust tehti videosalvestus, mille peaeesmärk oli jäädvustada neid mälestusi, mis võiksid esile kerkida vanu filme üle vaadates.

Filmimaterjali autor on Harald Perten. Ta sündis 1913 Eestis, pages 1944 Saksamaale, siirdus sealt edasi Rootsi ning hiljem Šveitsi, kus suri 1992. aastal. Eksiilajakirjandus on Perteni tegemiste ja saavutuste vastu alati suurt huvi tundnud, kuid eelkõige kirjutatakse temast kui maailmakuulsast teraviljakeemikust, kes ta tõepoolest ka oli (Eesti Päevaleht 1983: 2; Kokla 1992: 7). Oma töö kõrval jõudis ta harrastada tennist, auto- ja laskesporti ning - mis kultuuriloo seisukohalt kõige olulisem - fotograafiat ja filmindust. Filmi alal oli ta Rootsis eriti aktiivne 1940.-50. aastatel, mis muu hulgas viitab tõsiasjale, et selle aja kultuurielu oli sündmusterohke, kõiki ettevõtmisi peeti eestluse seisukohalt oluliseks ning püüti jäädvustada tulevaste põlvede tarvis. Pertenid lahkusid

Rootsist 1960. aastate kes-

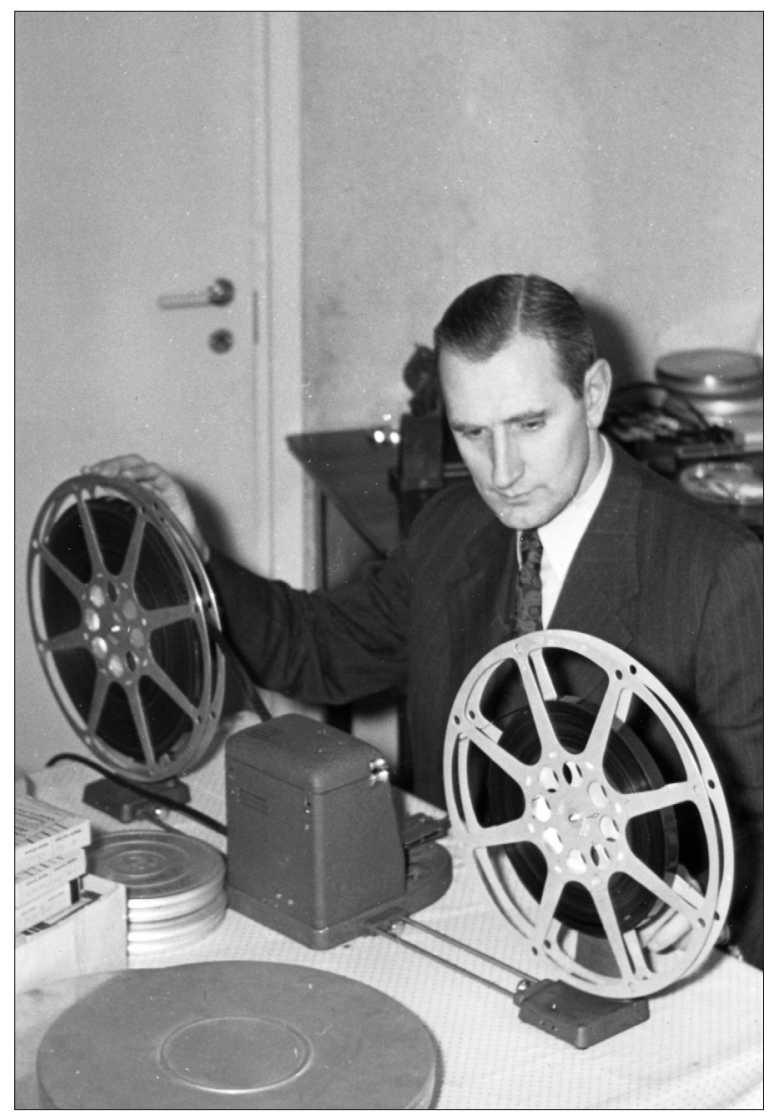
kel, kuid pärast Harald Perteni surma andis abikaasa Hella Perten tema pärandi hoiule Rootsi Eestlaste Lii$\mathrm{du}$ arhiivile, sealhulgas 50 kitsasfilmi (Raud-Pähn 2013: 25-28). 
Filmimehena on Perten töötanud üksi, kuid teinud Eesti Filmi nime all koostööd ka Olev Lellepiga. Mõne suurprojekti ajal oli meeskond veelgi arvukam, nt film "Eesti üldlaulupidu Stockholmis 27. juunil 1948"1 võeti üles mitme kaameraga ning tiitritest selgub, et lisaks Lellepile osalesid ka Mihkel (Michael) Lepper ja Paavo Loosberg, kellel oli fotograafiaga professionaalne suhe. Lepper õppis enne sõda Berliinis filmi- ja fototehnikat, sõjapäevil tegutses rindefotograafina ning eksiilis Teataja ja Eesti Päevalehe juures pressifotograafina (Kokla 1980: 8). Loosberg pidas Stockholmi tehnikaülikoolis fotograafia õppetooli assistendi ametit, hiljem õpetas Ohio fotograafiainstituudis tehnilist fotograafiat (http:// isik.tlulib.ee/index.php?id=72). Voldemar Kurese ${ }^{2}$ päevik kinnitab, et amatöörfilmindus oli rootsieestlaste hulgas laialt levinud hobi. Filme ei tehtud ainult oma pere tarbeks, vaid näidati ka seltskonnaüritustel ning tegijate vahel võis täheldada konkurentsigi. 18. septembril 1949 kirjutab Kures, et käis Vöhrmanni filmietendusel ning lisab: "Igal pool lõhed ja omaette tegemised, ka filmi alal. On nüüd kolm filmi - Perteni, Lellepi ja Vöhrmanni film” (Kures 2006: 35). Kultuuriloo seisukohalt rootsieestlaste filmiharrastusele tagasi vaadates tuleb filmimeheks number üks pidada siiski Pertenit. Mõned infokillud selle kohta, mida ja kuidas Perten filmis, võib leida jällegi Kurese päevikutest. Seoses esimese üldlaulupeo jäädvustamisega kirjutab Kures (2006: 288), et sügisel näitas Perten oma kodus ajakirjanikele ja laulupeotegelastele (Heinrich Laretei, Eduard Tubin, Verner Nerep) suvel ülesvõetud laulupeofilmi. Rongkäigule oli filmigrupp kulutanud tervelt kolm rulli, kuid laulupeokontserdile vaid ühe, sest rohkemaks polevat jätkunud raha. Laulupeokaadrid on kokku monteeritud Stockholmi vaadetega, mis Perten on hiljem juurde filminud; need moodustavad ligi neljandiku kogu filmist. Niisiis, ühest küljest pani filmidefitsiit piiri sellele, kui suurt osa kultuurisündmusest oli võimalik jäädvustada, kuid ka filmija subjektiivsel eelistusel oli üksjagu kaalu. Selle kohta pakub Kures veel ühe kõneka näite. 2. augustil 1953 filmis Perten Aino Kallase õnnitlemist 75. sünnipäeval tema kodus Stockholm-Hägerstenis Vattenledningsgatanil (Fakt 1953: 1). Kurese päevikust selgub, et ka tema viibis sünnipäevapeol, kuid filmiklipis me teda ei näe, nagu paljusid teisigi külalisi. Päevikus kirjutab Kures (2006: 146-149), et päeva jooksul käis Kallast õnnitlemas kokku 46 külalist, kuid Perten filmis ainult ühe rulli peale ning valis aja, mil kohal olid kõige silmapaistvamad poliitikud. Kurese saabudes valmistusid ministrid Rei ja Warma parajasti lahkuma ning filmimine oli juba lõpetatud. Kõnealune filmiklipp oli üks neist, millega töötas ka meie Stockholmi ekpertrühm. Tegemist on musta materjaliga ning sünnipäevast on mustvalgele filmile võetud üksikud episoodid kogupikkusega 00:02:36. Kommenteerimise käigus tuvastati Aino Kallase kõik üheksa külalist, kes selle aja sisse mahtusid: tütar Virve Ainikki Päss, minister Rei, minister Warma abikaasaga, piiskop Johan Kõpp abikaa- 
saga, professor Harald Perlitz abikaasaga, poliitikategelane Rudolf Moorma ning kirjanik, karskus- ja naisliikumisaktivist Helmi Mäelo. Korrigeeriti ka filmimise aega: esialgsetel arhiiviandmetel pärines materjal aastast 1948, kuid kommenteerimiseks eeltööd tehes olid arhiivigrupi liikmed kirjalike allikate toel välja selgitanud, et tegelikult toimus filmimine aastal 1953.

Pärast Kallase klippi jätkas ekspertgrupp tööd musta materjaliga, mis algselt kandis nimetust "Hindås 1948" (värviline, kestus 00:03:51). Rahvarõivais lauljad rivistuvad vabaõhulavale, peetakse kõnesid, koorid esinevad, lipud lehvivad, kaamera libiseb üle arvuka publiku, peatudes kultuuriloost tuntud nägudel, dirigendile ulatatakse tammepärg. Sisu poolest tüüpilise laulupeofilmi materjal, mille esialgne läbivaatus ei ennustanud mingeid probleeme. Kuid kõigist ekspertrühma kommenteeritud filmidest jäi just Hindåsi klipi juures lahtiseks sündmuse toimumise aeg, ning tegelikult ei leidnud täit kinnitust ka koht (või kohad) ega sündmus (või sündmused), mida me selles filmis näeme.

Järgneva uurimuse eesmärk on kirjeldada Hindåsi klipi analüüsimise käi$\mathrm{ku}$, tuua esile üleskerkinud probleemid ning otsida neile lahendusi, toetudes erinevatele interneti- ja trükiallikatele (eksiilajakirjandus, teatmikud jms). See on juhtumiuurimus, mille taustaks on üldisem küsimus korrastamatatuvastamata arhiivimaterjalide kultuuriloolisest väärtusest.

\section{Hindåsi klipi analüüs}

Digiteeritud filmimaterjali töödeldi programmiga TMPGEnc Authoring Works 5. Pilt projitseeriti suurele ekraanile, ekspertrühm nägi nii filmitud sündmust kui ka subtiitrite lisamist kaadritele, mis võimaldas kohe materjali läbivaatamise käigus teha märkusi ja parandusettepanekuid. Kogu tööprotsessist tehti videosalvestus, Hindåsi klipi (00:03:51) kommenteerimine kestis 26 minutit, sellest tehti videosalvestus (Janika Kronberg). Allpool on esitatud klipi läbivaatamise ajal kaadritele lisatud subtiitrid (kursiivis) koos kokkuvõttega kaadreid puudutavast arutelust. Klippi on võimalik vaadata aadressil http:// www.folklore.ee/tagused/nr63/. Kommenteerijad: Ivar Paljak (I. P.), Urve Toots (U. T.), Maria Kiisk (M. K.), Mai Raud-Pähn (M. R.-P.), Aino Inkapööl (A. I.), Tiina Mark-Berglund (T. M.-B.), Anne Maandi-Callius (A. M.-C.) ja Jüri-Karl Seim (J.-K. S.).

\section{Algustiiter 00:00:01 Hindås 19?? Filminud Harald Perten.}

M. R.-P. selgitab, et Perten on filminud Hindåsis Lääne-Rootsi suvepäevi, mille raames peeti ka väikest laulupidu. Kõik kommenteerijad on üksmeelel, et fil- 
mimise aeg (1948) on määratud ekslikult, kuna samal ajal toimus Stockholmis eesti pagulaste esimene üldlaulupidu ning kohalikke laulupäevi ei korraldatud. M. R.-P. täpsustab, et Hindåsi klipi õige aasta on 1947.

I. P. täiendab, et tema mälu järgi alustati suvepäevadega Hindåsis 1947 või 1948 ning neid toimus ka mitmel hilisemal aastal. Arutelu käigus meenub I. P.-le, et suvel 1946 oli ta ise Hindåsi skaudilaagris ja juba sellel aastal toimus kooride esinemine, mis tähendab, et klipi filmimise aeg võib põhimõtteliselt olla veelgi varasem. Kuid M. R.-P. jääb kindlalt 1947. aasta juurde. Tema andmetel oli suvepäevade laulupeoks nimetamisel kindel põhjus: 1947 moodustati Rootsis Eesti Lauljate Liit, kes korraldas suvepäevade ajal esimese kooride kokkutuleku Hindåsis. Vastukaaluks pakub J.-K. S. välja mõne hilisema aasta, kuna ta mäletab, et käis ise koos ema ja vennaga Hindåsi suvepäevadel millalgi viiekümnendatel. Aasta jääb esialgu lahtiseks, variantidena on kaalumisel 1946, 1947 või 1950. aastate esimene pool. Ühele neist võimalustest loodavad kommenteerijad kinnitust saada, kui Hindåsi klipp on tähelepanelikult lõpuni vaadatud ning filmis nähtud inimesed kindlaks tehtud.

\section{A-kaader 00:00:04 Norrköpingi ENMKÜ Meeskoori lipp.}

Lauljad on saabunud esinemispaika. Lipud asetatakse lava kõrvale ehitatud alusele: seal lehvivad Rootsi ja Eesti riigilipud, koorilippudest on ainsana võimalik tuvastada Norrköpingi Eesti Noorte Meeste Kristliku Ühingu Meeskoori lippu.

\section{B-kaader 00:00:33 Juhan Aaviku koori lauljad Stockholmist;} esiplaanil Aede Kivilo-Gold.

Lavale suundudes mööduvad esinejad kaamera eest, kommenteerijad püüavad tuvastada koore ja lauljaid. M. R.-P.: "Koore oli sellel ajal juba igas eesti keskuses, me ei tunne neid kõiki. Kui moodustati lauljate liit, siis see hakkas 1948. aasta üldlaulupidu ette valmistama, nii et Hindåsis oli nagu esimene suur proov enne laulupidu. Tuleb uurida vanu lehti, sealt saab teada rohkem kooridest.” I. P., M. K. ja J.-K. S. pole nõus: arvatakse, et filmile on jäänud ainult Lääne-Rootsi koorid, sest Hindåsis peeti Lääne-Rootsi eestlaskonna kokkusaamisi. Stockholmi suhtes oli Hindås perifeeria, kuhu oli tülikas sõita, mistõttu see paik ei sobi hästi ülerootsiliseks kooride kokkutulemiseks. Kuid M. R.-P. tunneb klipis ära Juhan Aaviku segakoori Stockholmist ${ }^{3}$ ja tuvastab kohe ka esimese Aaviku koori laulja Aede Kivilo-Goldi ning see fakt toetab tema väidet, et tegemist on ülerootsilise üritusega. 


\section{C-kaader 00:00:38 Kõneleb Balti Komitee esimees Birger Nerman (?)}

Koorid on lavale rivistunud, nende ees seisab peokõneleja, kes tuvastatakse kiiresti: M. R.-P. tunneb ära Birger Nermani ${ }^{4}$. J.-K. S. kinnitab, et see on tema - Balti Komitee esimees ja eesti pagulaste sõber. Birger Nerman läheb subtiitritesse kirja. Hiljem, subtiitrite lõpliku vormistamise käigus sunnib üks järgnev kaader (vt I) tema nime järele küsimärki kirjutama, sest eri kaadrites Nermanina tuvastatud isikud ei sarnane teineteisega kuigivõrd. Kõneleja võiks olla ka Heinrich Laretei ${ }^{5}$ (vt kaadrit H).

\section{D-kaader 00:01:16 Voldemar/Nikolai(?) Kaasik, Evald Uustalu,}

Evald Blumfelt ja Aksel Mark.

Publiku hulgast tunnevad kommenteerijad ära Nikolai Kaasiku, kuid J.-K. S. teeb paranduse: Kaasiku eesnimi on Voldemar. ${ }^{6}$ Tema kõrval istuvad endine diplomaat Evald Uustalu (Janika Kronberg lisab, et kuna Uustalu on töötanud ka kirjandusmuuseumis, siis teatakse teda hästi $)^{7}$, professor Evald Blumfeldt ${ }^{8}$ ja poliitikategelane Aksel Mark ${ }^{9}$. Kuna kommenteerijate hulgas on viimase tütar T. M.-B., küsib M. K., kui vana Aksel Mark filmiklipis võiks olla, lootes selle abil täpsustada filmimise aastat, mis on endiselt lahtine. Paraku tuleb T. M.-B.-lt vastuseks küsimus: “Mis aastal see on tehtud?" Jälgides, kuidas tuvastatud isikute nimed töö käigus kaadri alla ilmuvad, meenutab T. M.-B. üht ammust lugu: "Aksel kirjutatakse $k s$-iga. Mitte igaüks ei tea seda, siin Rootsis me kohe kirjutaksime Aksel $x$-iga. Eesti saatkond Londonis oli saatnud Aksel Margale - vaadanud arvatavasti telefonikataloogist aadressi - kutse, kui tuli üks esimesi vastuvõtte siin kusagil peenes kohas. Ja Heinrich Mark ${ }^{10}$ oli ka saanud. Heinrich Margale tuli kutse kohale ja Heinrich tuli siis Akseli käest frakki laenama. Siis hiljem tuli välja, et teine [kutse] oli saadetud kellelegi ingenjör Axel Margale kusagil Stockholmis. Aksel ei saanudki kätte... Aga ainult üks frakk oli ka."

Aksel Margalt suundub kaamera laiemale publikule, mitme eri nurga alt näidatakse üldplaane ning tundub, et rahvahulk võiks ulatuda vähemalt tuhandeni. M. R.-P. selgitab: “Tehniliselt - selle kohta on öeldud, et need pildid on võetud saja meetri kauguselt ülevalt tornist, mitte ei olnud seal helikopter. Suusahüppetorn. ${ }^{11} 6000$ inimest oli [peoplatsil].” Nii täpse arvu mainimine tekitab kahtlusi, A. M.-C. soovib teada, kust see pärineb, ning saab vastuseks, et nii on kirjutatud ajalehes. 


\section{E-kaader 00:01:42 Kõneleb Birger Nerman.}

Taas näidatakse põgusalt peokõnelejat, seekord profiilis; ta tuvastatakse kui Birger Nerman, diskussiooni ei teki.

\section{F-kaader 00:01:55 Ühendatud koore juhatab Verner Nerep.}

Kaadris on lauljad ja dirigent, kelles kommenteerijad tunnevad kohe ära Verner Nerepi. M. R.-P. meenutab: "Sõjaeelsel ajal oli Nerep Estonia orkestri juht ja tal oli siin ka oma orkester Stockholmi Eesti Seltsi juures, aga see lõpetas varsti." ${ }^{2}$ J.-K. S. lisab kinnituseks: "Ta õpetas ka Stockholmi eesti koolis, ta oli mu esimene muusikaõpetaja." Üles tõuseb küsimus, kes on Nerepi järglased Rootsis, selle üle arutletakse pikemalt ning tehakse selgeks, et praegu elab Stockholmis tema tütar Hilma Nerep-Mossin, kes alustas oma pianistikarjääri Eestis ning jätkas Rootsis.

\section{G-kaader 00:02:09 Norrköpingi ENMKÜ Meeskoori lipp.}

Kaamera suunatakse lippude rivile laululava kõrval. Norrköpingi Eesti Noorte Meeste Kristliku Ühingu Meeskoori lipp on esiplaanil ning selgesti on nähtav aastaarv $1947 . .^{13}$

\section{H-kaader 00:02:37 Peamin. EW presidendi ülesannetes August Rei, pr Therese Rei ja min Laretei.}

Näidatakse esireas istuvaid aukülalisi, kõik kommenteerijad tunnevad ära eksiilvalitsuse peaministri Eesti Vabariigi presidendi ülesannetes August Rei ${ }^{14}$, pr Therese Rei ja minister Heinrich Laretei. Esimest korda kommenteerimise jooksul kerkib küsimus, kas filmiklipp näitab meile ühte kontserti või on tegemist montaažiga mitmest eri sündmusest. Põhjuseks on asjaolu, et ehkki film on tehtud jaaniajal, kannavad aukülalised pakse mantleid, daamidel on kübarad peas, mõnel kindadki käes ning publikukaadrites on muru luitunud tooni. Samas lasevad kaadrid lauljatest aimata lausa südasuvist ilma. Kommenteerijad leiavad, et kübarad siiski ei pruugi viidata külmale ilmale. ${ }^{15} \mathrm{M}$. K.: "Mina mäletan, et Therese Reil olid alati kõige laiemad kübarad peas, kas oli nii?" A. I.: "Jah, mäletad õigesti. Alati tuli kirikusse kõige viimasena ja istus kõige ette. Aga talle meeldis ka laulda..." Kommenteerijad meenutavad Therese Rei lauluarmastust, ${ }^{16}$ arutelu pöörab humoorikaks. Seoses pr Rei kübaraga tekib küsimus, mis aasta kübaramoodi me klipis näeme - ehk aitaks see määrata filmimise aega? M. R.-P. ei usu, et sellest võiks abi olla, kuna pagulased ei vahetanud kübarat igal aastal. 
I-kaader 00:02:42 Pr Nerman, Dr Nerman, piiskop Johan Kõpp ja pr Marie Kõpp.

Klipp jätkub aukülalistega. Taas nimetatakse üksmeelselt Birger Nermani, kelle kõrval istub pr Nerman ning piiskop Johan Kõppu ${ }^{17}$ koos pr Marie Kõpuga. Paraku ei meenuta Birger Nerman I-kaadris seda Birger Nermanit, kes eespool tuvastati peokõnelejana (kaadrid C ja E), kuid kõrvutamine internetis leiduva fotoga ${ }^{18}$ veenab, et esireas istub tõepoolest Birger Nerman.

\section{J-kaader 00:02:52 Ühendatud koore juhatab prof Juhan Aavik.}

Dirigenti näidatakse profiilis, filmituna vastu valgust. Aaviku juhatamismaneer on aga üldtuntud, nii et tuvastamine toimub kõhklusteta.

\section{K-kaader 00:03:22?}

Filmitud on peo lõputsermooniat. Kaadris on kõnepidaja, keda ei tunne ära ükski kommenteerija.

\section{L-kaader 00:03:27 Soome või Rootsi külaliskoori esindajad annavad}

Juhan Aavikule üle pärja.

Pärja üleandjaid ei osata tuvastada, kuid üksmeelse arvamuse kohaselt on need külaliskoori esindajad. Aavik ja oletatav külaliskoori dirigent kätlevad ning kaamera suunatakse külaliskoorile, mis tuvastatakse selle põhjal, et nad ei kanna eesti rahvarõivaid. J.-K. S.: "Seal olid mingid soomlased, kes andsid üle aukirja või midagi, mis iseenesest annab viite, et see asi toimus kaunis hilja mitte '47 või '48, vaid viiekümnendatel." M. R.-P.: "See on soome koor, ühel on soome rahvariided seljas." U. T.: "Või rootsi?" M. R.-P.: "Ma ei ole kindel, kas see oli see Kansallis-Kuoro, igatahes see koor käis Rootsis." U. T.: "Ei, soomlasi siin ei ole.” J.-K. S. peab soomlasi põhimõtteliselt võimalikuks, kuid rõhutab jätkuks M. R.-P. väitele soomlaste kohta: “...mis tähendab, et see oli hiljem kui 1947.” M. R.-P.: "Palun, ma toon praegu paberid välja, mis on proua Perteni enda registreeritud, nii et see on '47." J.-K. S.: "Aga kas meil olid sidemed Soomega juba '47?" Kinnitatakse, et eesti ja soome koorilauljate sidemed ulatuvad tagasi Eesti Vabariigi aega, kuid Rootsis oli Kansallis-Kuoro esmakordselt eestlaste külaliseks alles $1954 .{ }^{19}$ Siiski, vaadates publikut - eelkõige rõivamoe seisukohalt - tundub, et filmimine on toimunud pigem neljakümnendatel. Diskussiooni soomlaste teemal lõpetab M. R.-P., kes on veendunud, et peaksime uurima ajalehti, kuna sealt selguks kindlasti, kas soomlased olid Hindåsis. 
Arutelu jätkub sellega, et püütakse kindlaks teha isikut, kes surub Aaviku kätt ja asub siis külaliskoori juhatama. J.-K. S. pakub, et see võiks olla keegi Lääne-Rootsi eestlane. M. R.-P. nõustub: “Üks, kes seda korraldas, selle nimi oli Leinveer ${ }^{20}$ ja see oli Boråsi eestlane, üks kooliõpetaja. Tema tänas pärast, see on ajalehest teada. Aga mina pole seda Leinveeri isiklikult kohanud, ma ei tea, mismoodi ta välja nägi." I. P.: "Oot-oot-oot! Leinveer see ei ole, seda ma tean kindlasti. Minu kooliõpetaja oli Valdur Leinveer kolm aastat. Mäletan teda väga hästi ja tema see ei ole. Kahjuks." M. R.-P.: "Siis ta on soomlane." J.-K. S.: "Ei pea olema soomlane, see võib olla hoopis teine aasta. Mis tähendab, et meil on väga ebaselge, mis aasta see ikkagi oli. Kas Kansallis-Kuoro oli kohal, me ei tea seda täpselt." Külaliskoori kõrval on näha ka lipualus, Soome lippu nende hulgas pole ning see räägib pigem vastu võimalusele, et külalised on tulnud Soomest.

\section{M-kaader 00:03:38 Kontsertföreningeni muusikajuht Johannes Norrby (?)}

Viimane kaader saab oma subtiitri alles kolm kuud hiljem, septembris 2015. Vahepealsel ajal on M. K. omaette edasi juureldes jõudnud arvamusele, et tuvastamata jäänud külalisdirigent võiks olla Kontsertföreningeni muusikaadministraator Johannes Norrby ${ }^{21}$ kes paguluse esimesel kümnendil eesti muusikainimestega tihedalt suhtles. ${ }^{22}$ Kuid lõplikku kinnitust sellele siiski pole ja nii jääb subtiitrit lõpetama küsimärk. ${ }^{23}$

Arutelu lõpul pöörduvad kommenteerijad tagasi küsimuse juurde, millal see sündmus on filmitud. M. K.: "Kas kogu see film on üldse tehtud samal aastal? Kas see võib olla tehtud eri aastatel ja hiljem kokku miksitud?" Teised kommenteerijad nõustuvad, et nii see tõenäoliselt ongi. Oletatakse, et algus on kindlasti filmitud 1947 ja muu osa (kooride esinemine) 1950. aastatel, kuna külaliskoor Soomest sobiks paremini sellesse aega. On ka kahtlejaid. M. R.-P. teeb veel kord ettepaneku dokumendid läbi vaadata, kuid J. K.-S. ei näe selles lahendust: "Sa ütled aasta dokumentatsiooni alusel, aga mitte muidu - mitte selle järgi, mida sa näed.” M. R.-P. nõustub, et nii see on, ning sellega on arutelu lõppenud.

Kaks olulisemat tähelepanekut Hindåsi klipi analüüsi kokkuvõtteks:

1. Filmi läbivaatamisel põhjustas kõige elavamat diskussiooni filmimise aasta ja külaliskoor, mille osas jäädi eriarvamusele. Lõpuks võeti seisukoht, et materjal on kokku monteeritud eri aegadel Hindåsis toimunud suvepäevakontsertidest. See oli kompromiss, mis võimaldas lõpetada diskussiooni. 
2. Mälu järgi tundsid kommenteerijad ära 15 inimest esinejate ja publiku hulgast, kellest kaks tuvastati siiski küsimärgiga (vt loetelu alaosast "Kokkuvõtvaid järeldusi"); üks esineja jäi kindlaks tegemata. Tuvastatud isikud pakuvad suurepärast lähtealust trükiallikatel põhinevaks jätkuanalüüsiks, kuna nad on eksiilühiskonnas laialt tuntud kultuurija poliitikategelased, kelle esinemisi kajastati sageli ajakirjanduses.

\section{Jätkuanalüüs trükiallikate põhjal}

Sellel perioodil, kui Pertenil oli põhimõtteliselt võimalik jäädvustada Hindåsi suvepäevi (st 1947-1952), ilmus Rootsis kolm eestikeelset ajalehte: StockholmsTidningen Eestlastele, Eesti Teataja / Teataja ja Välis-Eesti. Suvepäevadest kirjutatakse ootamatult palju, isegi üheleheküljeline Stockholms-Tidningen Eestlastele leiab nende sündmuste jaoks ruumi. Miks on see pagulastele nii tähtis? Ajalehtedest selgub, et suvepäevad polnud üksnes meelelahutusüritus: nende päevade peamine mõte seisnes võidupüha tähistamises, mida filmiklipi kommenteerimise käigus ei mainitud - rõhk asetus laulupeole, mis toimus suvepäevade raames. Teatavasti on võidupüha (23. juuni) riigitraditsioon, mida Eestis hakati juurutama 1934. President Päts on nimetanud võidupüha meie suurimaks rahvuspühaks, millega tähistatakse kõiki eestlaste võite. Päeva keskseks sündmuseks kujundati tulede süütamine minevikukangelaste ja olevikuloojate auks, ühtlasi pidid loitvad lõkked väljendama usku Eestisse, mis on igavesti vaba (Postimees 1939: 1). Paraku katkes võidupüha traditsioon juba 1940. aastal Nõukogude okupatsiooni tõttu. Ehkki traditsioon oli väga noor, jõudis see kinnistuda eestlaste meeles. 1944. aasta sõjapõgenikud viisid võidupühakombed kaasa võõrsile, kus selle tähistamine uutes oludes ja pisut muutunud kujul jätkus. Võidupüha n-ö väliseks vormiks eksiilis kujunesid suvepäevad (suvipäevad), neid hakati korraldama 23. juunile lähimal nädalalõpul. Kui võimalikuks osutus, süüdati tuli, kuid mõnikord jäi tulesüütamine lihtsalt sümboolseks kujundiks tähtpäevakõnes. Ajalehtede esikülgedelt võib leida eksiilpoliitikute ja kunstiinimeste juhtkirjalaadseid artikleid, kus vaadatakse tagasi traagilistele sõjasündmustele kodumaal, mis tegid lõpu vaba Eesti arengule. Pealkirja all "Kustunud võidutuled" meenutatakse Teatajas, kuidas presidendi saadikud vabaduseaastail tuld üle maa laiali kandsid. 1940. aasta okupatsioon algas kaks päeva enne võidupüha, kuid sellest hoolimata kogunes rahvas 23. juuni õhtul tule äärde laulma ja kõnelema vabadusest (Teataja 1945a: 1). On ka tulevikku suunatud kirjutisi: samas numbris kutsub minister Laretei kaasmaalasi üles jääma eestlasteks, hoidma rahvusluse tungalt kõrgel 
ning andma seda edasi oma lastele (Teataja 1945b: 1). Võidupühatulede traditsiooni jätkamises nägid eksiilpoliitikud tuge eesti identiteedile paguluses.

Ajalehtede põhjal võiks üsna hõlpsasti kokku panna rootsieestlaste suvepäevade lühikese ajaloo, kuid filmiklipi tuvastamise seisukohalt on olulised eelkõige Lääne-Rootsi üritused. 1945. aastal korraldati Hindåsis vanemskautrühma puhkelaager ja laagripäevade sisse jäi ka 23. juuni. Süüdati lõkketuli nagu võidupühale kohane, külla kutsuti kõiki ümbruskonna eestlasi, oli muusikat ja tantsu (Teataja 1945c: 3). 1946 tähistati Hindåsis taas võidupüha ja nüüd seoti see suvepäevade nimetusega. Hindåsi suvepäevad polnud ainsad sellel aastal, Eesti Teataja rubriik "Eestlased Rootsis" sisaldab infot suvepäevade korraldamisest kaheksas eri paigas. Suurem osa eestlasi elas linnades, kuid enamasti korraldati võidupühal väljasõit loodusesse. Ainult Uppsalas peeti võidupühaaktust ülikooli aulas, kõneles August Rei ja koori juhatas Juhan Aavik (Eesti Teataja 1946: 6).

1947. aasta 18. juuni Eesti Teataja esilehelt leiame reklaamteksti: "Hindås kutsub ja Hindås pakub huvitavat. Sõitke kolmeks päevaks Lääne-Rootsi eestlaste suvipäevale 22.-24. juunil s. a. Ulatuslik kava esitatakse 23. juunil. Näitus kõigest, mida teevad eestlased Rootsis." Artikkel "Saabub aeg heisata lippe" samas lehenumbris teatab ka suvepäevade filmimise kavatsusest: "Lääne-Rootsi eestlaste suvipäeva filmimise teostab Harald Perten Stockholmist. Filmile jäädvustatakse 23. juuni sündmused Hindåsis algusest lõpuni ja osa filmist tuleb tõenäoliselt värviline" (Eesti Teataja 1947a: 5).

Stockholms-Tidningen Eestlastele tutvustab suvepäevade eel põhjalikult Hindåsi kava, sellest selgub, et ürituse avab korralduskomitee esimees Leinveer, jumalateenistust peavad piiskop Kõpp ja metropoliit Aleksander, peokõnelejana astub üles Nikolai Kaasik ning kontsertosas esineb ühendatud segakoor Harry Truusi ${ }^{24}$ juhatusel (Fakt 1947: 1). Mõnda nimetatud isikutest võimegi näha Hindåsi klipis: aukülaliste reas istub piiskop Kõpp koos abikaasaga; publiku hulgas on ka Nikolai Kaasik (tuvastatud küsimärgiga). Kuid Leinveer ei ole filmile jäänud ning mis kõige olulisem - Truusi asemel juhatavad ühendkoori hoopis Nerep ja Aavik.

Ajakirjanduse läbitöötamine kinnitab, et prof Aavik oli 1947. aasta suvepäevadega otseselt seotud. 21. juuni Eesti Teataja on avaldanud tema artikli "Suvipäevad - rahvuslikud sündmused". Aavik kirjutab, et sellel suvel toimuvad Lääne-, Lõuna- ja Kesk-Rootsi suvepäevad, need sisaldavad jumalateenistusi, ühendkoorikontserte koos pidukõnedega ning rahvatantsijate ja võimlejate esinemisi. Ta toob välja ka suvepäevade seose 1948. aastaks kavandatava üldlaulupeoga: suvepäevade raamkava on põhimõtteliselt sarnane plaanitava laulupeoga, mistõttu tegelaste esinemine suvepäevadel kujuneb selle suur- 
ürituse eelprooviks (Aavik 1947: 2). Oma artiklis Aavik ei maini, kas ta peab silmas Lääne-, Lõuna- või Kesk-Rootsi suvepäevi, kuid see selgub mujalt. Sama Eesti Teataja avaldab kuuendal leheküljel lühikese kirjutise Kesk-Rootsi suvepäevade kohta ning sealt võime lugeda, et Norrköpingis juhatab koore Juhan Aavik (Eesti Teataja 1947b: 6) ehk siis - laulupeo eelproovi funktsiooni täidavad Norrköpingi suvepäevad. Hiljem ongi rootsieestlased hakanud seda sündmust nimetama Norrköpingi laulupäevaks (nt Äro 1969: 61).

Kui suvepäevade nädalavahetus oli möödas, tegi Eesti Teataja toimunust kokkuvõtte (Eesti Teataja 1947c: 1). Kõige olulisemaks hinnati seda, et suvepäevad äratasid tähelepanu ka kohalike rootslaste seas. Östergötlands Dagblad on ära trükkinud minister Laretei peokõne, mille ta pidas Norrköpingis. Borås Tidningen on kirjutanud, et Norrköpingi suvepäevadel oli kohal 5000-6000 välismaalast-eestlast, keda Rootsis üldiselt peetakse poolenisti kriminaalseks elemendiks, ja ainult kaks politseinikku, keda ei vajatudki. Leht tõi eestlasi rootslastele eeskujuks, mis oli pagulaste maine kujunemisel ülimalt tähtis asjaolu. Kuid käesoleva uurimuse seisukohalt on oluline pigem osavõtjate arv, mida kommenteerijad mälu järgi seostasid hoopis Hindåsi suvepäevadega (Hindåsi publikuarvu ajakirjanduses ei mainita).

Ajalehti läbi töötades selgus, et Hindåsi suvepäevadeks on trükitud ka teatmikke. Kõige varasem teatmik pärineb aastast 1946, see annab lühikese ülevaate programmist ja juhatab külalistele teed peopaika, mis on "raudtee jaamast ca $1200 \mathrm{mtr}$. ida suunas teest paremal pool asuval spordiväljakul" (Lääne-Rootsi... 1946: 9). 1947. aasta Hindåsi teatmik näitab, et suvepäevi peetakse seal juba kolmandat aastat järjest, tiitlil seisab: "Lääne-Rootsi 3. suvipäev Hindåsis 1947" (Lääne-Rootsi... 1947: 9). Info esinejate kohta kattub ajakirjanduses esitatuga, teatmikust lisandub üks uus fakt: lõpusõnad ütleb Boråsi Eesti Seltsi esimees Voldemar Brun. Võimalik, et tema ongi see kõneleja, keda K-kaadri subtiitris tähistab küsimärk.

Teatmike analüüsist selgub, et 1948. aastal muutus nii Lääne-Rootsi suvepäeva nimetus, toimumispaik kui ka programm: suvepäevi hakati nimetama jaanipäeva pidustusteks, neid korraldati Boråsi Eesti Seltsi pansionaadis Öregårdenis (Jaanipäeva pidustusi... 1948), laulukoore seal ei osalenud, ka rongkäiku ei toimunud. Hiljem võeti Lääne-Rootsis suvepäevade nimetus uuesti kasutusele, need hakkasid toimuma eri kohtades: Boråsis, Rävlandas, Ramnaslättenis jm. Tagasi tulid ka koorikontserdid, juhatasid Harry Truus ja Eero Tarjus. ${ }^{25}$ Teatmikes trükitud kavade põhjal pole Lääne-Rootsi suvepäevadel kunagi juhatanud koore ei Aavik ega Nerep, seal pole osalenud külaliskoore ei Soomest ega Rootsist. 1951. aasta teatmik on teistest mahukam ja ehkki suvepäevad toimusid Boråsis, sisaldab see kahte fotot Hindåsi 1947. aasta suvepäevade kohta: üks kujutab rongkäiku, teine ühendkoori laval seismas (vt foto 2 ja 3 ). 


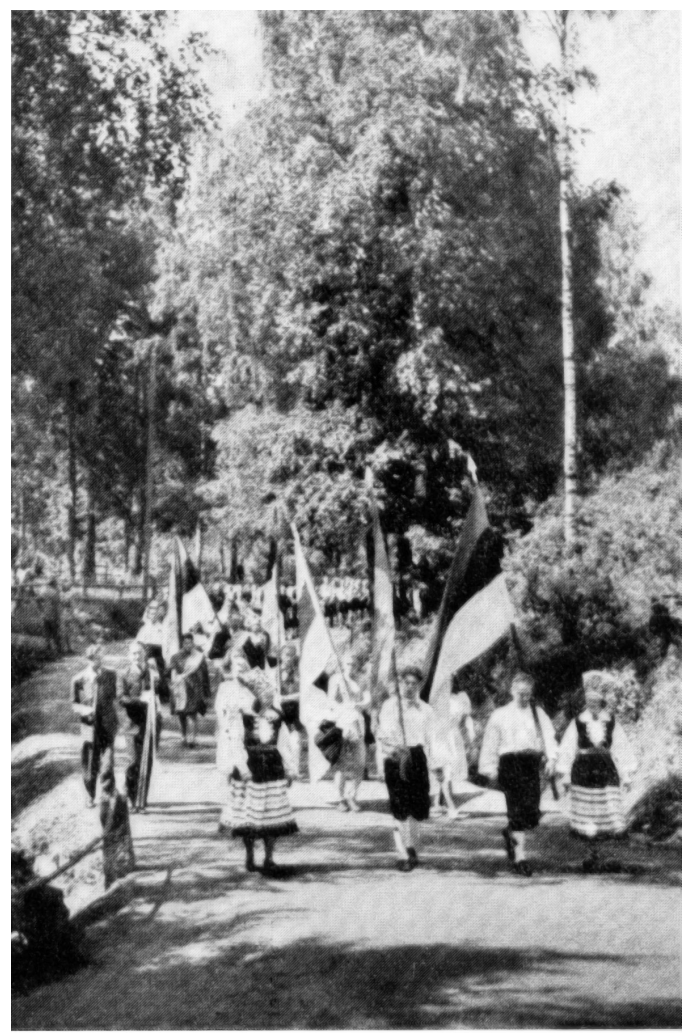

Sommarfest $i$ Hindås 1947

Foto 2. Suvipäevad Hindåsis 1947 (Lääne-Rootsi... 1951: 7).

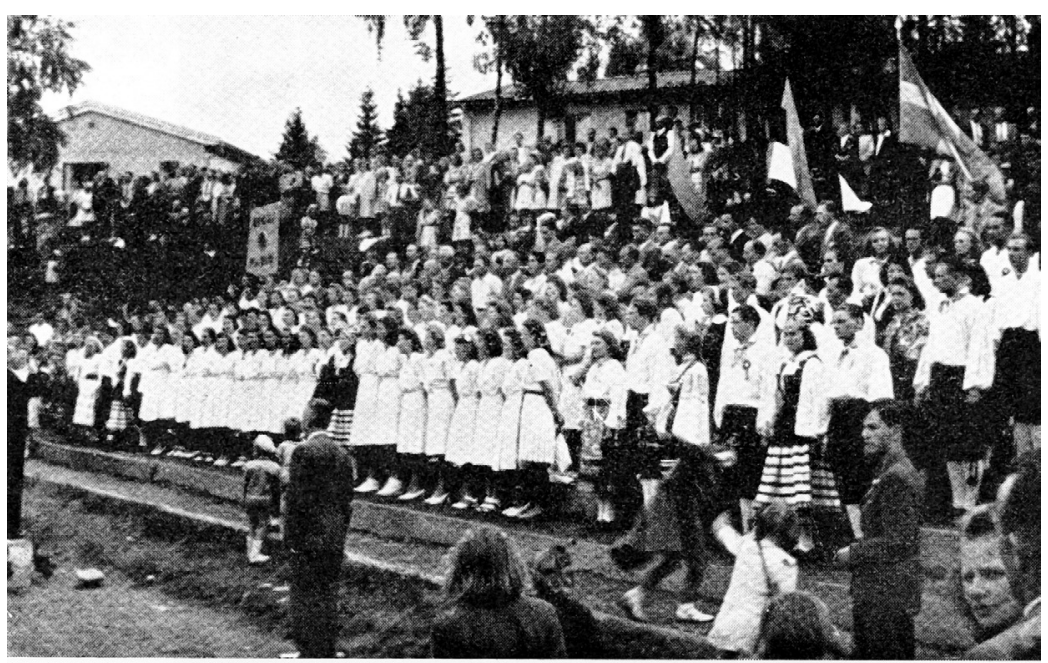

Sommarfest $i$ Hindås 1947

Foto 3. Suvipäevad Hindåsis 1947 (Lääne-Rootsi... 1951: 8). 
Eemalt paistab mõni maja ja kased, mis meenutab filmis põgusalt nähtud taustamaastikku. Kuid lava pole laudadest nagu filmis: koor seisab betoonastmestikul ning lauljadki on teised. Niisiis ei too fotodega teatmik loodetud kinnitust, et klipp on filmitud Hindåsis 1947. aastal.

Veel üks kord - 1952 - tuuakse Lääne-Rootsi eestlaste võidupüha tähistamine tagasi Hindåsi. See üritus kannab nime võidupüha-suvipäev (Lääne-Rootsi... 1952) ning on taas suurejoonelisem kui mitmel eelnenud aastal. Keskne roll on Eesti Üliõpilaskonnal Rootsis, peetakse kõnevõistlust Eesti Rahvusfondi auhindadele teemal "Vabaduses viibivate noorte ülesanded tänapäeval". Esinejad on tulnud pealinnast: laulab Stockholmi ENMKÜ Noorte Segakoor Olav Rootsi ${ }^{26}$ juhatusel ja peokõne peab minister Laretei, kuid viimane on ka ainus, mis võiks kokku sobida Perteni filmitud suvepäevadega.

Ajakirjanduse analüüsist selgus, et Hindåsi suvepäevadega samal ajal toimusid Norrköpingi suvepäevad. Hindåsi klipi kommenteerimisest jääb mulje, et need kaks on kommenteerijate mälus teatud määral kokku sulanud, seetõttu kontrollime oletust, et mingi osa klipist ongi Perten üles võtnud Norrköpingis. Teatmik näitab, et seal esinesid kõnedega Eesti-Rootsi Seltsi esimees Jaan Kask ja minister Laretei, koore juhatasid Juhan Aavik ja Olli Kask. ${ }^{27}$ Üritus toimus Hindåsiga sarnaselt spordipargis (Kesk-Rootsi... 1947: 4-5). Raamatu Eestlased Norrköpingis 1944-2000 vahendusel on ka fotomaterjal Norrköpingi suvepäevadest hõlpsalt kättesaadav. Paraku näitavad fotod, et Norrköpingi staadion ja lava (Adamson jt 2001: 33) erinevad täiesti sellest, mida võime näha filmiklipis. See lükkab ümber oletuse, et Perten on osa materjalist filminud Norrköpingis.

\section{Kokkuvõtvaid järeldusi}

Toimumispaik. Filmiklipi läbivaatamise kestel püsisid kommenteerijad üksmeelselt seisukohal, et film on üles võetud Hindåsis. Ehkki selliseid vaateid, mis võimaldaksid sündmuse toimumispaika vaieldamatult kindlaks määrata, filmile jäänud ei ole, tekib seda vaadates kujutlus künklikust maastikust, näha on ka järv - kommenteerijate kinnitusel on selline maastik iseloomulik just Lääne-Rootsile. Võimalik, et arvamust suunas ka teadmine, et publikut filmiti suusahüppetornist, mis oli Hindåsis 1940. aastatel tõepoolest olemas.

Isikud. Esinejate ja publiku hulgas istunud ühiskonnategelaste tuvastamine ei valmistanud ekspertrühmale erilisi raskusi: ära tunti Aede Kivilo-Gold, Verner Nerep, Juhan Aavik, Birger Nerman abikaasaga, Heinrich Laretei, August ja Therese Rei, Johan ja Marie Kõpp, Evald Uustalu, Evald Blumfeldt, 
Aksel Mark ja Nikolai/Voldemar Kaasik, ning neid mäletas hästi nii vanem põlvkond kui ka sõjajärgsel ajal üles kasvanud osalejad. Sündmuste ja isikute üle arutledes toetusid kommenteerijad eelkõige isiklikele mälestustele, mille tulemusel meenusid ka mitmed pisiseigad või lood, mis puudutasid klipis nähtud inimesi, kuid polnud otseselt seotud analüüsitava klipiga. Olulist mälutuge pakkusid arhiivis või ajakirjanduses varem nähtud fotod ja artiklid, kus kirjeldati suvepäeva-ja laulupeosündmusi ning loetleti seal osalenud prominentseid kultuuri- ja poliitikategelasi.

Märkamata jäänud faktid. Kõige suuremaks probleemiks osutus filmimise aasta kindlakstegemine. Hindåsi klipi kommenteerimise käigus jäi esialgu tähelepanuta kaks fakti, mis võimaldavad ajalisi raame täpsustada. G-kaadris on ENMKÜ Meeskoori lipul selgesti nähtav aastaarv 1947. See kinnitab, et filmiklipi materjal on (vähemalt osaliselt) filmitud aastal 1947 või hiljem, mitte varem, hoolimata sellest, et 1947 peeti suvepäevi juba kolmandat korda. Teiseks näeme D-kaadris Nikolai Kaasikut. See tähendab, et juhul, kui filmile on tõepoolest jäädvustatud just suvepäevakontsert, mis alati toimus juuni lõpus (ükskõik kas Hindåsis või mujal), sai filmimine aset leida mitte hiljem kui 1949, sest Kaasiku surmaaeg on 25. mai 1950. Ehk siis, D- ja G-kaader võimaldavad väita, et filmitud materjal pärineb ajavahemikust 1947-1949.

Jätkuanalüüsi tulemusi. Eksiilajakirjanduse ja teatmike läbitöötamisel selgusid järgmised faktid:

- Lääne-Rootsi suvepäevi peeti Hindåsis 1945, 1946, 1947 ja 1952 ning koorikontserdid toimusid staadionil.

- 1947 oli Harald Pertenil kavatsus filmida kõiki Hindåsi suvepäevaüritusi osaliselt mustvalgelt ja osaliselt värvifilmile. ${ }^{28}$

- 1947 pidas Hindåsis peokõne Nikolai Kaasik. Filmis nähtud Heinrich Laretei kõneles samal ajal Norrköpingi suvepäevadel ning Birger Nermani kõnet polnud kavas ei Kesk-, Lääne- ega Lõuna-Rootsi suvepäevadel.

- 1947 juhatas Hindåsis koore Harry Truus. Filmis nähtud Juhan Aavik juhatas samal ajal koos Olli Kasega koore Norrköpingi suvepäevadel ning Verner Nerep selle aasta suvepäevadel koore ei juhatanud.

Trükiallikatest selgus, et ainus suur kontsert 1940. aastate lõpul, kus publiku ette astusid lisaks laulukooridele piiskop Johan Kõpp, minister Heinrich Laretei ning dirigendid Juhan Aavik ja Verner Nerep, oli eestlaste esimene üldlaulupidu (Eesti Esimene Üldlaulupidu: 68-69). Neid kõiki (lisaks Balti Komitee esimees Birger Nerman ja Stockholmi kontserdimaja muusikajuht Johannes Norrby) võib näha ka Perteni filmis "Eesti üldlaulupidu Stockholmis 27. juunil 1948”, 
kuid muud ühist sellel filmil Hindåsi klipiga ei ole (st erinevad on toimumispaik, publik jne). Niisiis ei andnud filmimaterjali läbitöötamine Stockholmi ekspertide abil koos sellele järgnenud uurimistööga vastust küsimusele, millal ja kus on Harald Perten selle materjali filminud.

Mis oli filmiklippide tegemise mõte omas ajas? Terava sulega ajakirjanikuna tuntud Kures, kes tavaliselt oli oma kaastöödes patriootiliste tunnetega äärmiselt kokkuhoidlik, kirjutas pärast ühe kroonikafilmi esitlust:

Sündmused ja üritused kaovad tavaliselt märkamatult aega ja inimeste mälus tuhmuvad nad ruttu. Käesoleval korral aga on nad kustumatult jäädvustatud filmilindile, mis võimaldab kaasa elada möödunut ikka uuesti ja uuesti. See on suur väärtus ja seda peab hindama tõelise tänu avaldamisega EESTI FILMILE, kes vaatamata raskustele on suutnud ära teha sellise suure ja kuluka töö. Kui kord õnnestub tagasi minna Vabasse Eestisse, siis on need kroonikad ainukeseks dokumentaaltõendiks meie elust ja saatusest põgenikuna ning meie väärikaist püüdlusist kultuuri ja enesetutvustuse alal (Fakt 1948: 1).

Kuidas hinnata kõnealuse filmimaterjali väärtust enam kui pool sajandit hiljem, ehk mida suudab meile tõendada selline dokument nagu Hindåsi klipp, mille kohta me täpselt ei tea, millal, kus ja keda on jäädvustatud? Käesolev uurimus näitab, et kui sooviksime taastada pagulaselu kultuuriloo kronoloogilist kulgu sündmushaaval ja võimalikult detailselt, siis saaks seda teha ka ilma filmideta, nt eksiilajakirjanduse ja muude omaaegsete trükiallikate põhjal. Need annavad meile piisavalt fakte (mõnikord ka mõne pildi), kuid see jääb paratamatult formaalseks, kuivaks ja kaugeks. Vanad amatöörfilmid seevastu toovad eksiilühiskonna tegemised otse tänapäevainimese silmade ette. Isegi kui me kunagi ei leia vastust küsimusele, kus ja millal on Hindåsi klipp filmitud, näitab see ilmekamalt kui ükski ajakirjaartikkel, kuidas eksiilühiskond oli organiseerunud juba paguluse esimestel aastatel. See näitab kodumaiste rahvustraditsioonide ülekandmist võõrsile ning samas ka püüdlusi integreeruda uue asukohamaa ühiskonda, tuues oma kultuuri rootsi avalikku ruumi, leidmaks mõistmist ja lugupidamist. 


\section{Tänuavaldus}

Autor tänab Ivar Paljakut, Urve Tootsi, Maria Kiiska, Mai Raud-Pähna, Aino Inkapööli, Tiina Mark-Berglundi, Anne Maandi-Calliust, Jüri-Karl Seimi ja Mart Nurka, kes osalesid Harald Perteni filmidega seotud andmete täpsustamisel 5. ja 6. juunil 2015 Stockholmis. Ürituse algataja oli Maria Kiisk, selle teostamist toetas Rahvuskaaslaste Programm. Käesolev uurimus on seotud projektiga "Kirjanduse formaalsed ja informaalsed võrgustikud kultuuriloo allikate põhjal" (IUT22-2).

\section{Kommentaarid}

1 Esimene üldlaulupidu Rootsis kujunes üheks suurejoonelisemaks pagulaslaulupeoks üldse. Seal osales 14 sega-, 5 mees- ja 2 külaliskoori (Lüübeki Eesti Segakoor ja Stockholmi Körförbund) (Äro 1969: 61). Oma ülesehituselt järgis kogu üritus üsna täpselt eesti sõjaeelseid laulupeotraditsioone.

2 Voldemar Kures (1893-1987), ajakirjanik. Rootsis toimetas väljaannet StockholmsTidningen Eestlastele ja tegi kaastööd Eesti Päevalehele. Aastatel 2006-2009 andis tema päevikud välja kirjastus Ilmamaa, need sisaldavad väärtuslikke kommentaare kultuuri- ja seltskonnaelu kohta 1940.-50. aastatel.

3 Juhan Aavik (1884-1982), dirigent, helilooja ja laulupidude üldjuht. Enne Rootsi pagemist Tallinna konservatooriumi direktor (http://isik.tlulib.ee/index.php?id=1488). Juhan Aaviku segakoor asutati 1944. aasta detsembris Stockholmis (Aaviku memuaarid: 128), see oli amatöörkoor.

4 Birger Nerman (1888-1971), arheoloog, filosoofiadoktor. 1920. aastatel töötas lühikest aega Tartu ülikoolis eesti ja põhjamaade muinasteaduse professorina. Sõjajärgsel perioodil Stockholmis lävis tihedalt eesti pagulastega, tema nimi esineb sageli eksiilajakirjanduses seoses pidupäevaüritustega.

5 Heinrich Laretei (1892-1973), poliitikategelane, Eesti okupeerimise ajal saadik Rootsis. Pärast sõda juhtivatel kohtadel mitmes pagulasorganisatsioonis. Oma ühiskondliku positsiooni tõttu oli Laretei üks sagedasemaid peokõnelejaid paguluse esimesel kümnendil (http://isik.tlulib.ee/index.php?id=1637).

6 Voldemar Kaasiku kohta andmed puuduvad. Nikolai Kaasik (1933-1950), aktiivne eesti ühiskonnategelane Rootsis, mh Balti Humanistliku Ühingu esimees ja Eesti Rahvusfondi asutajaliige (http://isik.tlulib.ee/index.php?id=1469).

7 Evald Uustalu (1912-1982) lõpetas Tartu ülikooli ajaloolasena, sõjaeelsel ajal oli lühikest aega saatkonna atašee Berliinis. 1940-1941 töötas kirjandusmuuseumis sekretärina (http://isik.tlulib.ee/index.php?id=1526).

8 Evald Blumfeldt (1902-1981), ajaloolane, bibliograaf ja arhivaar. 1936-1940 töötas Eesti Kultuuriloolises Arhiivis, hiljem Tartu ülikoolis ajalooprofessor. Rootsis mitme teadusliku ühingu liige (http://isik.tlulib.ee/index.php?id=1506).

9 Aksel Mark (1913-2014), hariduselt agronoom. Rootsis tegutses ajakirjanikuna, kuulus siseministrina Eesti Vabariigi eksiilvalitsusse, oli Eesti Rahvusnõukogu esimees (http://isik.tlulib.ee/index.php?id=1995). 
${ }^{10}$ Heinrich Mark (1911-2004) lõpetas Tartu ülikooli õigusteaduskonna. Rootsis tegutses Eesti Komitee esimehe ja Eesti Rahvusnõukogu peasekretärina, oli Eesti Vabariigi eksiilvalitsuse peaminister presidendi ülesannetes (http://isik.tlulib.ee/index. php?id=1305).

${ }^{11}$ Hindåsi suusahüppetorn on unikaalne puitehitis aastast 1932, nüüdseks restaureeritud, kõrgus 45 m (Härryda-Posten). Satelliidipilt (Maplandia.com.) näitab, et suusahüppetorn asub tõepoolest staadioni läheduses, kus oletatavalt toimus filmitud koorikontsert.

${ }^{12}$ Verner Nerep (1895-1959), vahetult enne pagemist (1944) Estonia peadirigent. Sõjaeelsel ajal Eestis mitme laulupeo üldjuht; pagulaslaulupidude üldjuht Stockholmis 1948 ja 1954.

${ }^{13}$ Norrköpingi ENMKÜ Meeskoor asutati 1947 (Kangro 1976: 155).

${ }^{14}$ August Rei (1886-1963), vandeadvokaat, poliitik ja diplomaat. Eesti Vabariigi eksiilvalitsuse peaminister presidendi ülesannetes, Eesti Rahvusfondi ja Eesti Rahvusnõukogu esimees (http://isik.tlulib.ee/index.php?id=1654).

${ }^{15}$ Kommenteerimise selles järgus domineerib arvamus, et filmimine toimus 1947. Ilmavaatlejad on just selle aasta jaaniajal registreerinud kuumarekordi, mis läks ajalukku: nt Smålandis tõusis temperatuur 38 kraadini (List of extreme temperatures).

16 Therese Rei (1891-1976) õppis Peterburi konservatooriumis laulmist. Rootsis oli tuntud eelkõige seltskonnategelasena, jätkas ka lauluharrastust (Kint 1976: 7).

17 Johan Kõpp (1874-1970), vahetult enne Rootsi pagemist juhatas Tartu Usuteaduste Instituuti. Rootsis alates 1957 Eesti Evangeeliumi Luteriusu Kiriku peapiiskop (http:// isik.tlulib.ee/index.php?id=1085).

${ }^{18}$ Birger Nermani fotot vt nt Svenskt biografiskt lexikon.

19 Estonia Muusikaosakonna (EMO) segakoor valis Kansallis-Kuoro oma sõpruskooriks 1919. aastal, seejärel valis koor Juhan Aaviku oma auliikmeks. Paguluses taastas Aavik suhted Kansallis-Kuoroga ning kutsus nad esinema pagulaste teisele üldlaulupeole Stockholmis 1954 (Ojamaa 2015: 120-121).

${ }^{20}$ Valdur Leinveer õpetas Alingsåsi eesti algkoolis alates 1945/46. õppeaastast (Kits 2000: 35).

${ }^{21}$ Johannes Norrby (1904-1994), koorijuht ja Stockholmi kontserdimaja muusikajuht.

${ }^{22}$ Norrby oli aukülaliseks 1948. aasta üldlaulupeol, kus andis Aavikule üle tammepärja (Kangro 1976: 149).

${ }^{23}$ Teine rootsi dirigent, kellel olid pikaajalised suhted eesti kooriringkondadega, oli Sven Bergman, ta juhatas rootsieestlaste esimesel üldlaulupeol Stockholms Körförbundi (Eesti Üldlaulupidu Rootsis: 69). Fotomaterjal tema kohta pole kättesaadav.

${ }^{24}$ Harry Truus (1904-1994) õppis dirigeerimist Tallinna konservatooriumis August Topmani juures. Rootsis elas Göteborgis, kus juhatas mitut eesti koori, oli ka kõigi pagulaslaulupidude üldjuht (Eesti Raadio 1998).

${ }^{25}$ Eero Tarjus (1917-2005) õppis Tallinna konservatooriumis koorijuhtimist kuni 1944. aasta põgenemiseni. Paguluses juhatas Lüübeki Eesti Segakoori ja Göteborgi Eesti Meeskoori (http://isik.tlulib.ee/index.php?id=396).

${ }^{26}$ Olav Roots (1910-1974), dirigent ja pianist. Enne pagemist Riigi Ringhäälingu Sümfooniaorkestri peadirigent. Rootsis tegutses peamiselt pianistina, 1952 kutsuti Bogotásse Columbia sümfooniaorkestri peadirigendiks. 
${ }^{27}$ Olli (Olga) Kask (1906-1991), muusikaõpetaja ja koorijuht. Paguluses juhatas Norrköpingi Eesti-Rootsi Seltsi Segakoori ja Norrköpingi Eesti Meeskoori (http://isik.tlulib. ee/index.php?id=2899).

${ }^{28}$ Kinnituseks selle kohta, et Perten oma kavatsuse teostas, võiks olla tema film "Eestlaste suvepäevad Lääne-Rootsis Hindas" (1947), mis on siin analüüsitavast filmist erinev. See on must-valge filmikroonika kestusega 00:7:39, annotatsioonist selgub, et pidustused avas Leinveer, jumalateenistusel kõnelesid piiskop Kõpp ja metropoliit Aleksander, peakõne pidas Nikolai Kaasik, esines Lääne-Rootsi ühendatud segakoor jne (Eesti Filmi Andmebaas).

\section{Allikad}

Aaviku memuaarid = Juhan Aavik. Muusika radadelt VI. Mälestusi ja mõlgutusi eluteelt . Rootsis. Käsikiri. EKLA, reg. 2014/116.

Eesti Filmi Andmebaas = Eestlaste suvepäevad Lääne-Rootsis Hindas 23.06.1947. Eesti Filmi Andmebaas (http://www.efis.ee/et/filmiliigid/film/id/13499 - 4. veebruar 2016).

Eesti Raadio 1998 = Arhivaarsed avastused. Zelia Aumere ja Harry Truus. Eesti Rahvusringhäälingu arhiiv (https://arhiiv.err.ee/vaata/arhivaarsed-avastused-zeliaaumere-ja-harry-truus - 5. veebruar 2016).

Härryda-Posten = Gustavsson, Peter. Hoppbacken renoveras. Härryda-Posten, e-tidningen (http://www.harrydaposten.se/2014/04/hoppbacken-renoveras/ - 5. veebruar 2016).

List of extreme temperatures $=$ List of extreme temperatures in Sweden. Wikipedia. The Free Encyclopedia (https://en.wikipedia.org/wiki/List_of_extreme_temperatures_ in_Sweden - 5. veebruar 2016).

Maplandia.com = Hindas Map. Maplandia.com. Google maps world gazetteer (http://www. maplandia.com/sweden/goteborgs-och-bohus-lan/harryda-kommun/hindas/ - 5. veebruar 2016).

Svenskt biografiskt lexikon = Birger Nerman. Svenskt biografiskt lexikon . Riksarkivet. (https://sok.riksarkivet.se/sbl/Presentation.aspx?id=8838 - 5. veebruar 2016).

TLÜAR. Väliseesti isikud. Väliseesti isikulooline andmebaas (http://isik.tlulib.ee/ 5. veebruar 2016).

\section{Kirjandus}

Aavik, Juhan 1947. Suvipäevad - rahvuslikud sündmused. Eesti Teataja, 21. juuni, lk 2. Adamson, Kusta \& Pundi, Arnold \& Äro, Johannes (toim) 2001. Eestlased Norrköpingis 1944-2000. Tartu: Paar.

Eesti üldlaulupidu Rootsis = Eesti üldlaulupidu Rootsis Stockholmis, 26.-27. juunil 1948. Stockholm: Eesti Laulupeo Peatoimkond. 
Eesti Päevaleht 1983 = H. Perten 70 aastane. Eesti Päevaleht. Estniska Dagbladet, 7. aprill, lk 2 .

Eesti Teataja 1946 = Eestlased Rootsis. Eesti Teataja, 22. juuni, lk 6.

Eesti Teataja 1947a = Saabub aeg heisata lippe. Eesti Teataja, 18. juuni, lk 5.

Eesti Teataja 1947b = Kesk-Rootsi eestlaste suvipäevad. Eesti Teataja, 21. juuni, lk 6.

Eesti Teataja 1947c = Võidupüha suurte pidustustega. Eesti Teataja, 28. juuni, lk 1.

Fakt [Voldemar Kures] 1947. Hindås valmis vastu võtma külalisi. Stockholms-Tidningen Eestlastele, 20. juuni, lk 1.

Fakt [Voldemar Kures] 1948. Mis me oleme korda suutnud saata Rootsis. StockholmsTidningen Eestlastele, 20. jaanuar, lk 1.

Fakt [Voldemar Kures] 1953. Aino Kallase sünnipäeval. Stockholms-Tidningen Eestlastele, 4. august, $1 \mathrm{k} 1$.

Jaanipäeva pidustusi... 1948 = Jaanipäeva pidustusi. Öregården, 1948. Borås.

Kangro, Bernard 1976. Eesti Rootsis. Ülevaade sõnas ja pildis. Lund: Eesti Kirjanike Kooperatiiv.

Kesk-Rootsi... 1947 = Kesk-Rootsi eestlaste suvepäevad Norrköpingis 22.-23. VI 1947. Norrköping.

Kint, Tõnis 1976. Therese Rei mälestuseks. Teataja, 19. juuni, lk 7.

Kits, Aino 2000. Eesti Komitee Koolitoimkonna tegevus koosolekute protokollide (19451949) põhjal. Tuna 1, lk 32-41 (http://www.arhiiv.ee/public/TUNA/Artiklid_Biblio/ KitsAino_Eesti_komitee_TUNA2000_1.pdf - 8. veebruar 2016).

Kokla, Juhan 1980. Michael Lepperit mälestades: elu fotograafiale. Eesti Päevaleht. Estniska Dagbladet, 16. mai, lk 8.

Kokla, Juhan 1992. Harald Pertenit mälestades. Rahvusvahelist tunnustust leidnud teraviljakeemik. Eesti Päevaleht. Estniska Dagbladet, 20. mai, lk 7.

Kures, Voldemar 2006. Seitsme lukuga suletud raamat. III köide. Tartu: Ilmamaa.

Lääne-Rootsi... 1946 = Lääne-Rootsi eestlaste suvipäev Hindåsis 1946. Borås.

Lääne-Rootsi... 1947 = Lääne-Rootsi 3. suvipäev Hindåsis 1947. Borås.

Lääne-Rootsi... 1951 = Lääne-Rootsi eestlaste suvipäev Boråsis 1951. Borås.

Lääne-Rootsi... 1952 = Lääne-Rootsi eesti organisatsioonide ühine Võidupüha-Suvipäev Hindåsis. Borås.

Ojamaa, Triinu 2015. Rootsi aeg Juhan Aaviku elus: pagulasmemuaarid. Tuna 1, lk 116-122.

Postimees 1939 = Vaba ja sõltumatu Eesti rahvas! Vabariigi Presidendi K. Pätsi läkitus Võidupühaks. Postimees, 22. juuni, lk 1.

Raud-Pähn, Mai 2013. Harald Perten - maailma tuntumaid eestlasi. Rahvuslik Kontakt 4, lk 25-28. 
Teataja 1945a = Kustutatud võidutuled. Teataja, 20. juuni, lk 1.

Teataja $1945 \mathrm{~b}=$ Võidupühaks. Teataja, 20. juuni, lk 1.

Teataja 1945c = Boråsi skautrühma puhkelaager. Teataja, 20. juuni, lk 3.

Äro, Johannes 1969. Üksteistkümmend üldlaulupidu. Kronoloogiline ülevaade. VI Eesti

Üldlaulupidu Rootsis. Eesti üldlaulupidude 100 aasta juubeli tähistamiseks 24. mail

1969 Stockholmis. Stockholm: Eesti Lauljaskond Rootsis, lk 34-68.

\section{Summary}

\section{Film clip as a document of cultural history: The case of Hindås}

\section{Triinu Ojamaa}

Keywords: film clip, Estonians Swedes, refugee life, song festival, summer fest

At the end of the 1940s, a viable Estonian exile community was formed in Sweden; it mainly consisted of the World War II refugees. During the first two decades, an amateur film maker, Harald Perten, recorded the most important events of the Estonian Swedes (i.e. Estonians living in Sweden). He produced some longer silent films which chronicled life in exile. The films contain subtitles with the name of the event as well as some other data. Yet, a large part of his recordings stayed unexploited. The "raw material" belongs to the Estonian Archives in Sweden and presently the concrete data about those clips are missing, i.e., it is unclear when and where Perten filmed those clips. Based on a clip of such kind (working title "Hindås 19??"), the current article describes the course of identification of the filmed cultural event and people participating in it.

The study was designed as a two-step analysis:

1. The analysis of the film clip Perten supposedly made at an exile Estonians' summer fest. A group that consisted of eight Estonian-Swedish experts (they had participated in the cultural life of their diaspora group since the end of the war) watched the clip with an aim to identify from memory the people and the event. They were successful in identifying the former - the prominent Estonian-Swedish cultural and political figures. The question whether the clip had been filmed at the end of the 1940s or at the beginning of the $1950 \mathrm{~s}$ caused disagreement among the experts.

2. The analysis of the print sources was based on the exile Estonian newspapers and summer fest booklets. It became apparent that the Hindås summer fest, which merged St. John's Day with the national Victory Day and a small song festival, took place in 1947. Alas, at the same time, Estonian Swedes celebrated the fest in eight different regions all over Sweden. According to the newspaper articles and booklets, some people identified in the Hindås clip actually took part in different summer fests. 
In the course of the analysis, the year of the filmed event remained unclear. For different reasons, we cannot be sure whether this event actually took place in Hindås. While discussing the cultural-historical value of the unidentified film clips, we can say that even if we do not know the exact data, those clips nevertheless can be regarded as a unique source that demonstrates the cultural life of a well-organised exile community as well as the early cultural contacts with the representatives of the host country.

The Hindås clip with subtitles is available on the Internet at http://www.folklore. ee/tagused/nr63/. 